\title{
Model of Theory Writing for Applied Master Thesis Based on Genre
}

\author{
Nur Hasyim ${ }^{1)}$, Ade Sukma Mulya ${ }^{2)}$, Abdillah ${ }^{3)}$, dan Darul Nurjanah ${ }^{4)}$ \\ ${ }^{1}$ Jurusan Akuntansi, PNJ, Kampus Baru Depok, Jawa Barat, 16424 \\ ${ }^{2}$ Jurusan Akuntansi, PNJ, Kampus Baru Depok, Jawa Barat, 16424 \\ ${ }^{3}$ Jurusan Akuntansi, PNJ, Kampus Baru Depok, Jawa Barat, 16424 \\ ${ }^{4}$ Jurusan Teknik Sipil, PNJ, Kampus Baru Depok, Jawa Barat, 16424 \\ E-mail: hajinurhasim@gmail.com
}

\begin{abstract}
The Theory section of the applied master thesis is not easy to write. Research that has investigated the writing efforts and strategies for these parts is also not found. Therefore, this article presents a theoretical part writing model in a genre-based applied master thesis. This model is the result of research conducted with a development research approach. The result is (i) the main needs that need to be written in this section are to describe the theory so that this section needs to be written on the basis of text and report descriptions, (ii) description is the type of text that explains something as it really is; the structure of the description text is (a) something that is explained, (b) part of something described, (iii) report is a type of text that classifies something in its class; Report text structure is (a) things that must be reported, (b) classes / subclasses, (iv) description texts and report texts have linguistic characteristics that are used that need to be referenced so that the author is able to write the theory section correctly and quickly
\end{abstract}

Keywords - Theory, applied master thesis, genre, description, report.

\section{INTRODUCTION}

Theory is a very important thing in research because in this section it is necessary to explain the theories related to the focus of the research, previous relevant studies, and the research mindset so that the beginner writer often has difficulty writing it. They lack understanding about what to write and how to write it. On the other hand, research that has investigated the approach and method of writing part of the theoretical basis is also not found. In connection with research on the writing of this thesis, the research found was a study investigating the move analysis in (i) Introduction, and (ii) Research Results and Discussion, namely "Rhetorical Structure of Introduction Chapters written by Novice Vietnamese TESOL postgraduates" (Loan and Pramoolsook; 2016) and "Move Analysis of Chapters in TESOL Master's Theses Results-Discussion Written by Vietnamese Students" (Loan and Sook, 2015). Because there has been no research that addresses this problem, the writing model is formulated. Theoretical basis of the applied genre-based master's thesis is still considered to be a chance to be investigated, the results of which are written in this article with a focus on the description of the theory writing model in the applied master thesis genre.

The preparation of the genre-based theory writing model is carried out based on genre. Genre is a type of text. The theory was developed by Martin (2007), Santosa (2009), and Wiratno and Santosa (2011). Genre is a social process that is oriented towards a goal that can be achieved gradually (a staged goaloriented social process). In genre theory, it is understood that (i) every stage of communication (including the stage of communication in writing Research Results and Discussion) there is a need/ social process, (ii) writing of each social need / process can be used by certain genre/ type of text that is appropriate, (iii) there are eight micro genres: description, report, storytelling, procedure, explanation, exposition, discussion and exploration; description: texts that describe things as they really are (what things are as they are): shape, size, nature; report: grouping various things into types; procedure: instructional/giving instructions $/$ in the form of steps; 
storytelling/recount: narrating past experiences; explanation: cause and effect something happens; something happens because of another; exposition: one-sided argumentation: proposed dissertation argument; discussion: two-sided argumentation: respond to controversy from two points of view; the author can support one point of view; exploration: reporting something that is happening, (iv) certain micro genres have a certain text structure and linguistic characteristics: verbs, adjectives, and conjunctions used, (v) those linguistic characteristics when guided, the authors will be able to write down the needs of each section (paper) correctly and quickly

\section{Methodology}

$\mathrm{m}$ The article material which was presented in this study was the result of research which was carried out with a development research approach, namely research which was used to produce certain products and test the effectiveness of the product (Sugiyono, 2006). The product in this research is a genre-based theory writing model. The research steps (i) studying the results of previous research related, (ii) compiling prototype models, (iii) carrying out FGDs with language experts to get input on the prototype models that have been compiled, (iv) conducting prototype trials, (v) implementing FGD to discuss the results of the trial prototype model, and (vi) produce a translation model for the root words and invented words. In this research article, the results of the research step (i) to (iii) are presented. The data of this study, namely information relating to the writing of genrebased applied master thesis is collected with (i) literature study, (ii) conducting FGD with language experts, and (iii) direct observation of students who are preparing an applied master's thesis. Meanwhile, after being collected, the data were analyzed with qualitative analysis: (i) domain analysis, (ii) taxonomic analysis, (iii) compound analysis, (iv) analysis of cultural themes, then the analysis results were used to compile the model.

\section{RESULT AND DISCUSSION}

\section{A. Result}

The paradigm of the applied theory writing model of master's thesis is based on genres, as follows.
First, when writing theory, know what needs to be written down, as we know that in the Theory chapter it is necessary to write theory, previous research, and research mindset

Second, after finding out that the need to describe the three things is known that the type of text that is suitable for writing these needs is the text of the description and report text.

Third, in accordance with systemic functional linguistics, description text is very suitable to be used to describe theory, previous research that is relevant, frame of thinking of research. Report text is very suitable to be used to classify theories.

Fourth, the authors really need to understand the structure of the description and report text. Structure of Text Text Description and Report

1) The structure of the description text is (i) something described, (ii) the parts of something described.

2) The structure of the report text is (i) something reported, and (ii) class or subclass of something

Fifth, the author needs to understand the linguistic characteristics of the interpretation text and report text to be used as a reference in writing.

The following are linguistic features of description and report text. The descriptions used to describe the data are more (i) using additive conjunctions, such as and, and, and besides, (ii) using material verbs, which are verbs whose processes can be observed, including collecting, grouping, analyzing, conclude, find, and formulate; (iii) using relational verbs, which can be used to make definition sentences; in Indonesian, the definition sentence is indicated by the use of the word is, is, or is, (iv) using an adjective, to express conditions, such as good, bad, important, and less important.

Linguistic characteristics of the type of report text used to classify / classify data are more (i) using conjunctions such as if and based on (ii) using material verbs, which are verbs whose processes can be observed, including collecting, analyzing , concluding, finding, and formulating, (iii) using relational verbs, which can be used to make 
definition sentences; in Indonesian, the definition sentence is indicated by the use of the word is, is, or is, (iv) using the number word, to convey the number (class / category).

\section{Model of Theory Writing for Applied Master Thesis Based on Genre}

Cultural norms and values are realized in social processes. In fact, there are two types of social processes: verbal and non verbal. Verbal social process is a social process in which language is mainly used in the process in which language is the core, whereas non-verbal process is peripheral. This type of verbal social process includes teaching and learning process in the classroom, reading

\begin{tabular}{|c|c|c|c|c|c|}
\hline \multirow[t]{2}{*}{$\begin{array}{l}\text { Sosial } \\
\text { Proses }\end{array}$} & \multirow[t]{2}{*}{$\begin{array}{l}\text { Text } \\
\text { Type }\end{array}$} & \multirow[t]{2}{*}{$\begin{array}{c}\text { Text } \\
\text { Structure }\end{array}$} & \multicolumn{3}{|c|}{$\begin{array}{c}\text { Linguistics Characteristifews spaper, or listening to the radio, and others. In } \\
\text { of the Text }\end{array}$} \\
\hline & & & $\begin{array}{l}\text { Conju } \\
\text { nction }\end{array}$ & $\begin{array}{c}\text { Verb/ } \\
\text { Proce } \\
\text { ss }\end{array}$ & $\begin{array}{l}\text { Use } \\
\text { Adjeeqlled 'genre'. On the other hand, non-verbal } \\
\text { ve osocial process will include social process in which } \\
\text { Numpanguage is only peripheral' whereas the core is the } \\
\text { al non-verbal social process. The examples of non- }\end{array}$ \\
\hline $\begin{array}{l}\text { Describe } \\
\text { Theories } \\
\text { and } \\
\text { Classify } \\
\text { Theories }\end{array}$ & & & & & $\begin{array}{l}\text { verbal social processes are available in economics, } \\
\text { sports, politics, arts, and others. } \\
\text { From the example text description can be seen the }\end{array}$ \\
\hline $\begin{array}{l}\text { Describe } \\
\text { Theories }\end{array}$ & $\begin{array}{l}\text { Descrpti } \\
\text { ve }\end{array}$ & $\begin{array}{l}\text { Something } \\
\text { s } \\
\text { described; } \\
\text { the parts of } \\
\text { something } \\
\text { described }\end{array}$ & $\begin{array}{l}\text { Additi } \\
\text { on } \\
\text { Conju } \\
\text { ntion: } \\
\text { and, } \\
\text { besides } \\
\quad \text { in } \\
\text { other } \\
\text { hand }\end{array}$ & $\begin{array}{l}\text { Materi } \\
\text { al } \\
\text { Proces } \\
\text { s, } \\
\text { Relati } \\
\text { onal } \\
\text { Proces } \\
\text { s }\end{array}$ & $\begin{array}{l}\text { Uses use of conjunctions besides, and, in other hand. As } \\
\text { adjectiv is known that the conjunctions are conjunctions } \\
\text { e word that are widely used in the description text. } \\
\text { The following is an example of a report text which } \\
\text { is used to describe the theory. Cited from Hasyim } \\
\text { (2013) }\end{array}$ \\
\hline $\begin{array}{l}\text { Classify } \\
\text { Theory }\end{array}$ & Report & $\begin{array}{l}\text { Something } \\
\text { reported; } \\
\text { class or } \\
\text { subslass of } \\
\text { something }\end{array}$ & $\begin{array}{l}\text { Assumt } \\
\text { ion } \\
\text { Conjun } \\
\text { tion, } \\
\text { like: if, }\end{array}$ & $\begin{array}{l}\text { Materi } \\
\text { al } \\
\text { Proces } \\
\text { s, } \\
\text { Relati } \\
\text { onal } \\
\text { Proces } \\
\text { s }\end{array}$ & $\begin{array}{l}\text { If we look at the types of language functions } \\
\text { numefle conveyed by experts, the function of language } \\
\text { word can be divided into three: ideational, interpersonal, } \\
\text { and textual. Ideational functions are related to } \\
\text { the delivery of ideas; Interpersonal functions } \\
\text { relate to that we need to pay attention to aspects of } \\
\text { the delivery and recipient of ideas; Textual }\end{array}$ \\
\hline
\end{tabular}

The following is an example of a description text which is used to describe the theory. Cited from Santosa (2009)

In linguistics, the term genre is often paid less attention. This is because formal and structural linguistics tend to see that the object of language study is sentence. Besides, many linguists view language as atomistic-dualistic reality; such as langue and parole (Barthes, 2007; Saussure, 1966) and competence and performance (Chomsky, 1957, 1975). The linguists' resistance to use the term genre nowadays is also influenced by the fact that the term genre is already used in literature or arts which are considered as unscientific (Swales, 1990).
From an example above, we can see that is used conjunction if to do classifying the item. Function of classifying on theory so make a clear concept or theory.

\section{B. Discussion}

The findings of this study are very important because no research has investigated the strategy of writing theory based on a particular paradigm. In connection with the writing of the applied master's thesis, the facilities that already exist are Writing Guidelines, not writing strategies.

The results of the literature study note that the existing writing studies focus on move analysis, as 
has been done by Loan and Sook (2015) in the writing of the Introduction and Loan and Pramoosook (2016) in writing Research Results and Discussion. The move analysis of theoretical writing has never been done / researched. Thus, research on theoretical writing is still very open and needs to be done.

\section{CONCLUTION}

The writing model of the theory section in the genre-based applied master's thesis in the viewer's perspective is very important and indispensable. In order to implement this model, training and assistance is needed so that it can be understood and applied. Use of the model is recommended to understand the type of text so that when writing is more appropriate and directed in accordance with the genre-based paradima of writing.

\section{Acknowledgement}

This research article is the result of a research entitled Model of Theory Writing for Applied Master Thesis Based on Genre that was funded by the DRPM of Republik Indonesia. Therefore, we thank you for your willingness to finance this research. Thank you also to the Manajemen Seminar Politeknik Negeri Padang State who has provided the opportunity for this article to be discussed and published.

\section{REFERENCE}

(1) Badger, Richard dan White, Goodith. (2015). A Process Genre Approach to Teaching Writing. Language Teaching Research, Vol. 19 (3): 301-323

(2) Cargill, M. dan O'Connor, P. (2009). Writing Scientific Research Articles: Strategy and Steps. Sussex: John Wiley \& Sons.

(3) Hyland, Ken. (2007). "Genre pedagogy: Language, Literacy and L2 Writing Instruction". Dalam Journal of Second Language Writing, Volume: 16, Issue: 3, Pages: 148-164.

(4) Loan dan Pramoolsook. (2015). Move Analysis of Results-Discussion Chapters in Tesol Master's Theses Written by Vietnamese Students. 3L: The Southeast Asian Journal of English Language Studies - Vol 21(2): 1 - 15.

(5) Loan dan Pramoolsook. (2016). "Rhetorical Structure of Introduction Chapters written by Novice Vietnamese TESOL postgraduates". Dalam $3 L$ : The
Southeast Asian Journal of English Language Studies - Vol 20 (1): 61 -74

(6) Martin, J.R. (1992). English text: System and structure. Amsterdam: John Benjamins Publishing Company.

(7) Martin, J.R. dan David Rose. (2007). Working with Discourse. London: Continum.

(8) Politeknik Negeri Jakarta. (2015). Peraturan Pendidikan Politeknik Negeri Jakarta Nomor: 2491/PL3/SK/2003.

(9) Santosa. (2009). "Genre in Media Discourse". Dalam Article in Journal of Bahasa Sastra dan Studi Amerika, English Department, 2009.

(10) Shabudin. (2013). Interdiskursiviti dalam Wacana Iklan Produk Kecantikan Berbahasa Jepun. GEMA Online ${ }^{\circledR}$ Journal of Language Studies 149 Volume 13(2), May 2013.

(11) Speadly, J.P. (1980). Participant Observation. New York: Rinehart and Winston.

(12) Sugiyono. (2006). Metode Penelitian Pendidikan: Pendekatan Kuantitatif, Kualitatif, dan $R \& D$. Bandung: Alfabeta.

(13) Wiratno, Tri dan Santosa, Riyadi. (2011). Pengantar Linguistik Umum. Jakarta: Universitas Terbuka. 